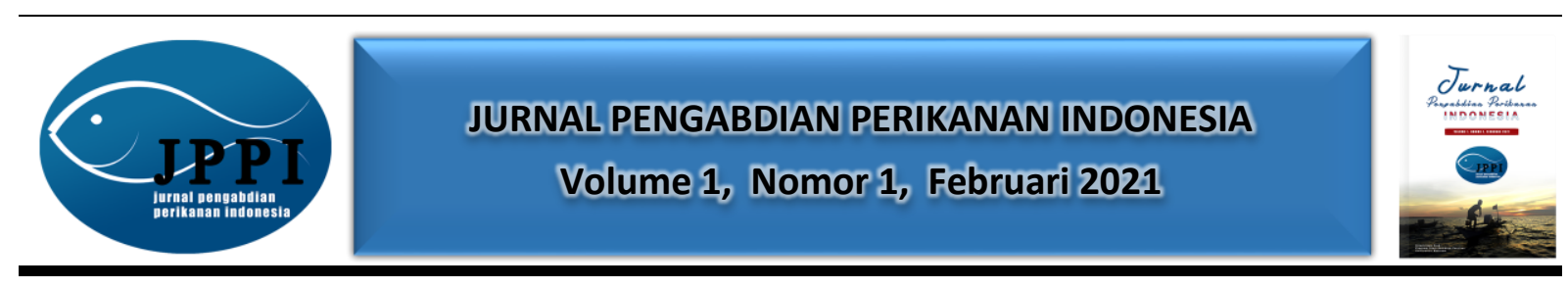

\title{
PEMANFAATAN ALAT PENGERING IKAN LAUT MENGGUNAKAN TENAGA SURYA DI DESA PEJALA KABUPATEN TANAH BUMBU
}

\author{
Agus Irawan ${ }^{1}$, Muhammad Teguh Nuryadin², Hairul Anwar ${ }^{2}$, Anhar Khalid $^{3}$, Yusuf \\ Rizal Fauzi ${ }^{3}$, Mey Risa ${ }^{4}$ \\ ${ }^{1}$ Program studi manajemen informatika, Politeknik Negeri Banjarmasin; ${ }^{2}$ Program \\ Studi Administrasi Bisnis, Politeknik Negeri Banjarmasin; ${ }^{3}$ Program Studi Teknik Mesin, \\ Politeknik Negeri Banjarmasin; ${ }^{4}$ Program Studi Administrasi Bisnis, Politeknik Negeri \\ Banjarmasin.
}

Alamat korespondensi : agusirawan@poliban.ac.id

(Tanggal Submission: 3 Desember 2020, Tanggal Accepted : 2 Februari 2021)

\begin{abstract}
Keyword: Abstract:
pengolahan Masyarakat nelayan di desa Pejala Kabupaten Tanah Bumbu saat ini mengolah hasil tangkapan ikan, ikannya menjadi ikan asin untuk dijual di pasaran. Adapun teknik pengeringan ikannya masih pengering manual yang mengandalkan cuaca cerah dirasa kurang efektif karena faktor cuaca yang sulit ikan, tenaga diprediksi. Bila dibiarkan terus menerus tentunya berakibat pada menurunnya kuantitas dan surya kualitas produksi ikan asin serta berpengaruh pada pendapatan/kesejahteraan mereka. Solusi yang dipilih adalah pemanfaatan teknologi tepat guna yaitu membuat alat pengolah/pengering ikan asin laut yang hemat energi dan tidak dipengaruhi oleh faktor cuaca/alam seperti hujan. Tujuannya dengan penggunaan alat ini dapat meningkatkan pendapatan/kesejahteraan nelayan secara umum. Sehingga target yang diharapkan adalah satu tahun berikutnya dan seterusnya nelayan-nelayan melalui kelompoknya bisa mandiri dalam mengelola bentuk usahanya baik proses perencanaan, produksi dan pemasarannya. Adapun bentuk Metode kegiatan yang akan dilaksanakan meliputi (1) Koordinasi dengan pihak terkait (Poliban-Pemda/Perangkat Desa) untuk membina kelompok nelayan (UKM) setempat; (2) mengidentifikasi permasalahan dan menentukan solusi; (3) membuat alat pengering ikan teknologi tepat guna yang efektif dan efisien memanfaatkan energi tenaga surya; (4) melakukan pelatihan dan pendampingan dalam proses produksi dan pemasaran. Hasil dari kegiatan pengabdian yang dilaksanakan berupa peningkatan kualitas dan kuantitas produk hasil pengolahan ikan dan hasil laut serta sungai, sehingga masyarakat mampu meningkatkan penghasilan.
\end{abstract}

Panduan Sitasi (APPA $7^{\text {th }}$ edition) :

Irawan, A., Nuryadin, M.T., Anwar, H., Khalid, A., Fauzi, Y.R., \& Risa, M., (2021). Pemanfaatan Alat Pengering Ikan Laut Menggunakan Tenaga Surya Di Desa Pejala Kabupaten Tanah Bumbu. Jurnal Pengabdian Perikanan Indonesia, 1 (1), 13-20. http://doi.org/ 10.29303/jppi.v1i1.38

\section{PENDAHULUAN}

Sebagai negara kepulauan terbesar didunia dengan $2 / 3$ wilayahnya adalah laut. NKRI memiliki banyak wilayah laut, pesisir, dan pulau-pulau kecil yang luas dan bermakna strategis sebagai pilar pembangunan ekonomi nasional. Khusus untuk hasil ikan tangkapan potensi 
Indonesia sangat melimpah sehingga dapat diharapkan menjadi sektor unggulan perekonomian nasional. Untuk itu potensi tersebut harus dimanfaatkan secara optimal dan dilestarikan terutama upaya meningkatkan alat tangkap yang modern bagi nelayan dengan terus melakukan bantuan, pendampingan dan pembinaan secara kontinyu. Tugas ini merupakan tanggung jawab bersama antara pemerintah, masyarakat, dan pengusaha guna meningkatkan pendapatan masyarakat dan penerimaan negara yang mengarah pada kesejahteraan rakyat. Jadi potensi hasil ikan tangkapan dapat di konsumsi oleh warga kita bahkan bisa di eksport ke luar negeri. Peningkatan daya jual harus diimbangi dengan produkproduk olahan yang berkualitas.

Nelayan di desa Pejala Kabupaten Tanah Bumbu provinsi Kalimantan Selatan memiliki banyak KUB (Kelompok Usaha Bersama) diantaranya KUB Pada Idi dan KUB Lamuru. Namun dalam proses produksi ikan asin hasil tangkapan masih menggunakan cara tradisional, terutama proses penjemuran yang masih mengandalkan cuaca cerah. Padahal saat ini sulit untuk mempridiksi cuaca, bahkan curah hujan akhir-akhir ini cukup tinggi. Hal ini mengakibatkan banyak ikan yang busuk dan terbuang sia-sia, ditambah lagi system penyimpanan belum bagus menumpuk kurang bersih, ini berimbas pada menurunnya produksi dan menurunnya kualitas hasil ikan olahan.

Solusi dari masalah tersebut perlu adanya teknik pengeringan ikan sebagai alternatif dan alih teknologi untuk menunjang jumlah produksi ikan tetap tinggi serta membangun system pergudangan yang memadai untuk menstok dan mengemas hasil ikan olahan agar lebih berkualitas. Diharapkan harga jualnyapun bisa lebih baik.

Sebagaimana kegiatan pengabdian masyarakat (PKM) yang pernah diangkat oleh Herlina herlina, Dian Aswita, Ikramullah Zein dari Universitas Serambi Mekkah Banda Aceh. PKM ini memberikan solusi dengan memanfaatkan teknologi berupa oven solar dryer sebagai upaya peningkatan hasil produksi ikan asin yang higienis di wilayah pesisir kota Banda Aceh, dengan metode alih teknologi.

Sasaran dari kegiatan PKM di desa Pejala adalah untuk meningkatkan produktifitas warga khususnya KUB setempat. Sedangkan Tujuan kegiatan PKM ini adalah : (1) Meningkatkan kuantitas produk; (2) Meningkatkan kualitas produk dan (3) Membenahi system pergudangan stok produk.Adapun lokasi PKM berjarak $243 \mathrm{~km}$ dari ibukota provinsi Kalimantan Selatan yaitu kota Banjarmasin (Politeknik Negeri Banjarmasin), dengan waktu tempuh kurang lebih 5 jam 10 menit.

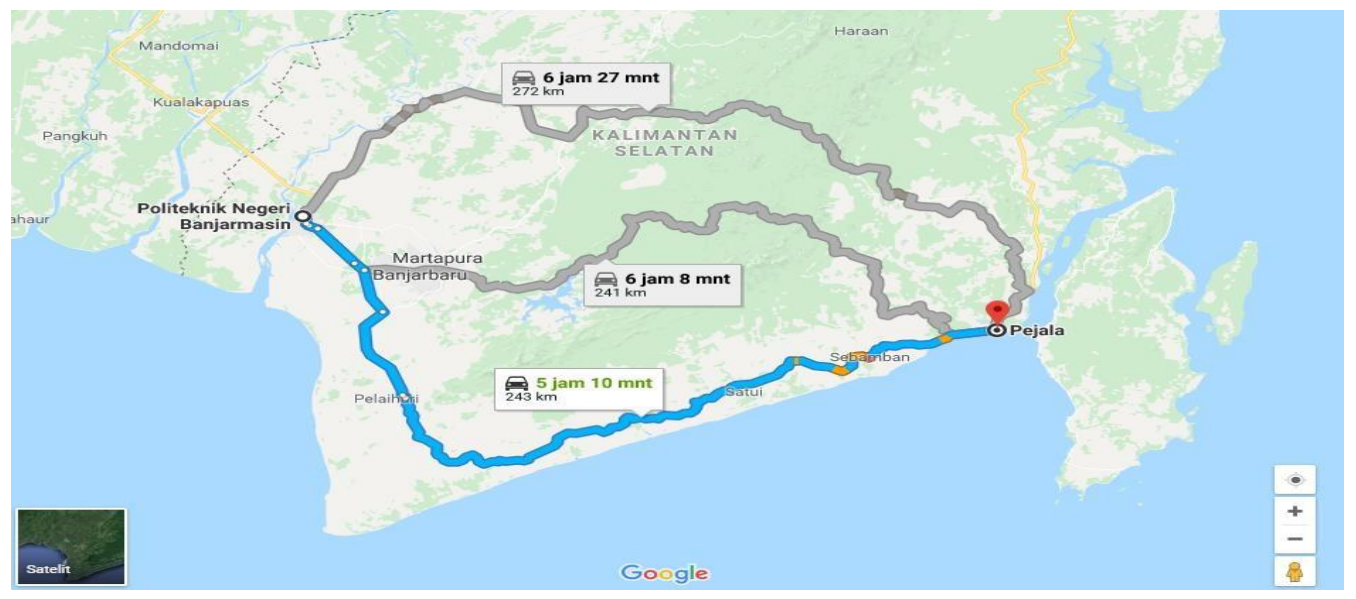

Gambar 1. Peta lokasi pelaksanaan kegiatan 


\section{METODE KEGIATAN}

Kegiatan pengabdian kepada masyarakat ini dijalankan melalaui beberapa tahapan yang dapat dilihat pada Tabel 1. Langkah awal sebelum itu, tim pelaksana kegiatan melakukan analisis situasi pada mitra kegiatan yang terlibat. Alat uji analisis yang digunakan adalah Analisis SWOT.

Tabel 1. Tahapan kegiatan pengabdian kepada masyarakat

\begin{tabular}{|c|c|c|}
\hline No & Kegiatan & Keterangan \\
\hline 1 & $\begin{array}{l}\text { Survey / Pendekatan } \\
\text { kepada masyarakat }\end{array}$ & $\begin{array}{l}\text { - Diskusi tim pelaksana kegiatan dengan mitra } \\
\text { - FGD tim dan mitra ke lokasi produksi ikan dan gudang stok } \\
\text { - Tinjau tempat penjemuran tradisional } \\
\text { - Pengukuran objek ikan }\end{array}$ \\
\hline 2 & $\begin{array}{l}\text { Diskusi Tim Pelaksana } \\
\text { Kegiatan }\end{array}$ & $\begin{array}{l}\text { - Design alat dan rehabilitasi gudang } \\
\text { - Menyusun anggaran kegiatan } \\
\text { - Mekanisme kerja tim } \\
\text { - Menentukan spesifikasi alat }\end{array}$ \\
\hline 3 & Kegiatan Lapangan & $\begin{array}{l}\text { - Bengkel (pembuatan alat) } \\
\text { - Mitra KUB (merombak gudang produksi) }\end{array}$ \\
\hline 4 & $\begin{array}{l}\text { Pelatihan dan penyerahan } \\
\text { bantuan teknologi }\end{array}$ & - Sosialisasi tim dengan aparat desa, KUB, dan warga \\
\hline
\end{tabular}

Hasil ujia analisis SWOT pada mitra dapat dijabarkan sebagai berikut :

Kekuatan (strength):

(1) Masyarakat usia produktif relatif besar;

(2) Wilayah mitra yang dekat dengan laut;

(3) Potensi ikan tangkapan yang besar di perairan laut jawa dan selat Sulawesi;

(4) Semangat Organisasi/kemasyarakatan untuk membangun Desa masih tinggi;

(5) Biaya tenaga kerja murah;

(6) Harga produk terjangkau;

(7) Proses produksi yang ramah lingkungan.

Kelemahan (weakness):

(1) Komposisi tingkat pendidikan yang rendah;

(2) Bahan baku cepat rusak;

(3) Rendahnya penguasaan teknologi tepatguna;

(4) Tempat penjemuran yang masih minim dan sederhana;

(5) Kualitas ikan masih belum optimal karena saat penjemuran rentan terkontaminasi;

(6) Teknik penyimpanan dan pengemasan masih kurang higinies. 


\section{Peluang :}

(1) Lokasi yang relatif mudah dari jalan Propinsi sehingga mempermudah distribusi pemasaran;

(2) Perkembangan teknologi pengeringan ikan;

(3) Peluang pengelolaan pariwisata perikanan;

(4) Tingginya permintaan terhadap produk hasil laut;

(5) Dukungan kebijakan pemerintah;

(6) Potensi pasar yang besar;

(7) Ketersediaan media promosi dan periklanan

\section{Ancaman :}

(1) Banyaknya kompetitor-kompetitor lain untuk produk sejenis baik skala kecil maupun besar;

(2) Cuaca yang sering berubah dapat menyebabkan terganggunya proses produksi;

(3) Timbulnya pandemic Covid-19.

Implementasi Kegiatan kegiatan PKM, adalah : (1) Mendesain dan membuat alat pengering ikan tenaga surya yang dikombinasikan dengan tenaga listrik dengan pengatur suhu dan waktu yang disesuaikan dengan jenis ikan; (2) Mendesain dan merombak .
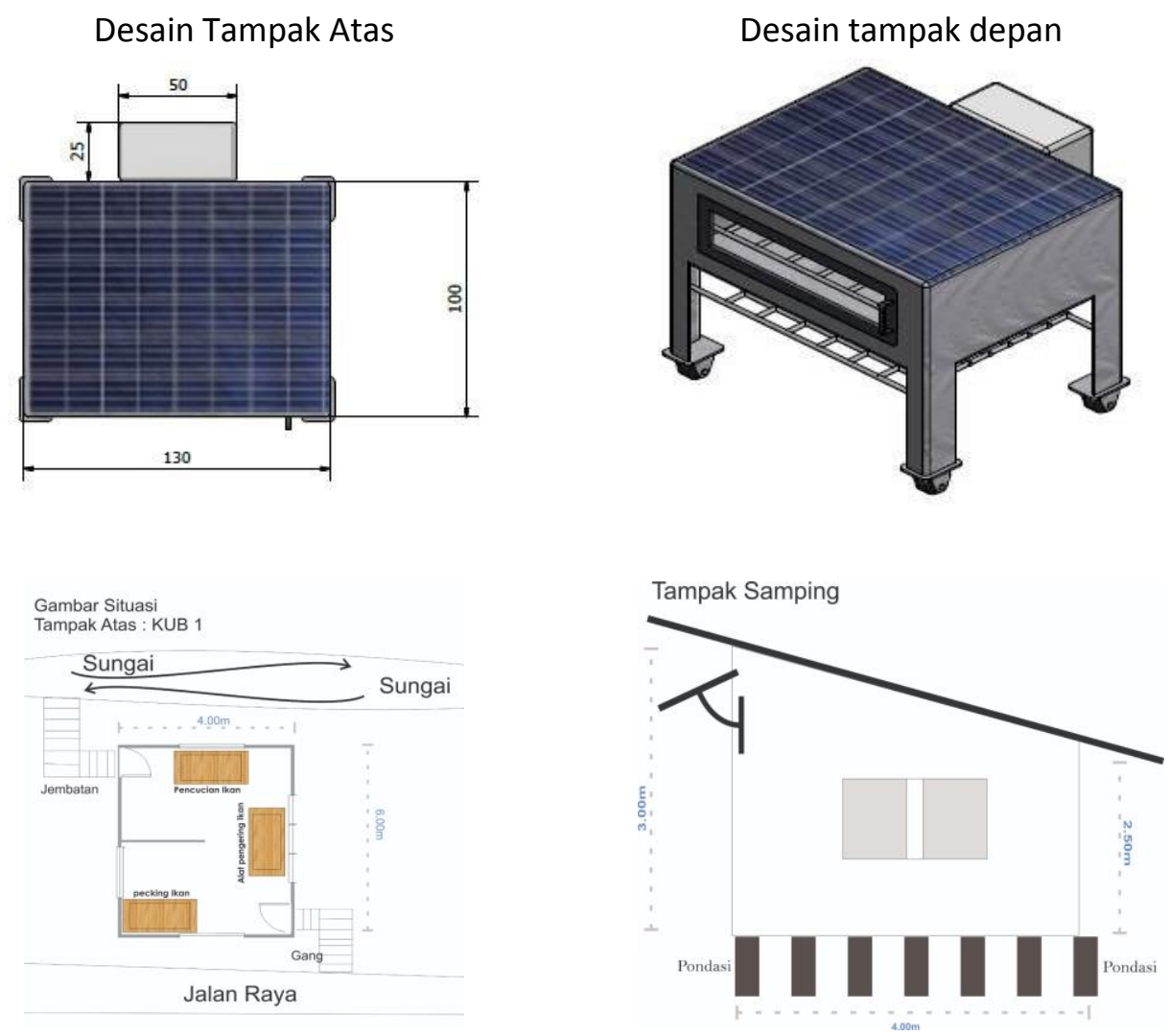

Gambar 2. Design alat yang digunakan pada kegiatan pengabdian kepada masyarkat 
Desain alat dengan spesifikasi :

1. Solar cell Polycrystalline $12 \mathrm{~V}$

2. Bateeray $12 \mathrm{~V} 140 \mathrm{Ah}$

3. Inverter $12 \mathrm{~V} 2000$ watt

4. Solar Control system PWM $20 \mathrm{~A}$

5. $\mathrm{MCB} 4 \mathrm{~A}$

6. Temperatur Control XH W3001

7. Power Supply $12 \mathrm{~V} 3 \mathrm{~A}$

8. Stopkontak isi 2
9. Terminal Blok isi 12

10. Heater AC $220 \mathrm{~V} 40$ watt $80^{\circledR}$

11. Fan $12 \mathrm{~V} 12 \times 12 \times 1 \mathrm{~cm}$

12. Panel Box $60 \times 40 \times 20 \mathrm{sm}$

13. Kabel NYA $1.5 \mathrm{~mm}$

14. Kabel NYM $1.5 \mathrm{~mm}$

15. Steker

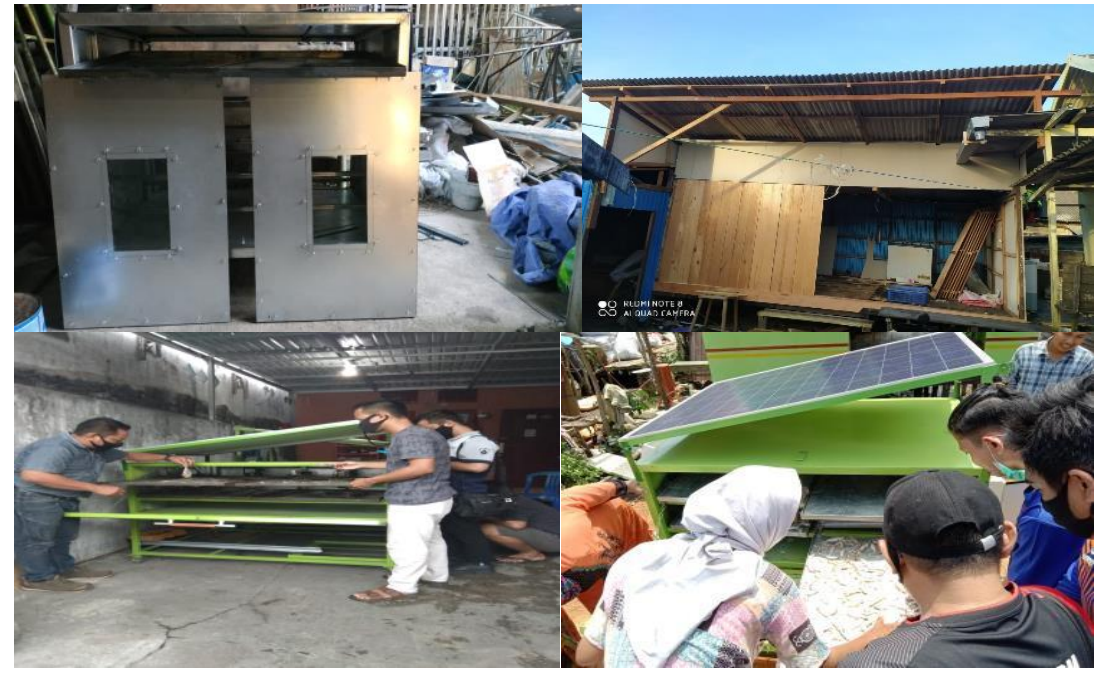

Gambar 3. Perakitan peralatan pada kegiatan pengabdian

Agar sasaran dan tujuan kegiatan PKM di desa Pejala tercapai dengan baik, maka tim melakukan pendekatan melalui metode :

1. Model Participatory Rural Appraisal (PRA) yang menekankan keterlibatan masyarakat dalam keseluruhan kegiatan mulai dari perencanaan, pelaksanaan dan evaluasi program kegiatan.

2. Model Participatory Tecnology Development yang memanfaatkan teknologi tepat guna yang berbasis pada ilmu pengetahuan dan kearifan budaya lokal.

3. Model Community development yaitu pendekatan yang melibatkan masyarakat secara langsung sebagai subyek dan obyek pelaksanaan kegiatan pengabdian kepada masyarakat.

4. Persuasif yaitu pendekatan yang bersifat himbauan dan dukungan tanpa unsur paksaan bagi masyarakat untuk berperan aktif dalam kegiatan ini.

5. Pendekatan yang baru akan dilaksanakan dalam kegiatan pengabdian masyarakat di desa Pejala adalah pendekatan edukatif yaitu pendekatan sosialisasi, pelatihan dan pendampingan sebagai sarana transfer ilmu pengetahuan dan pendidikan untuk pemberdayaan masyarakat.

\section{HASIL DAN PEMBAHASAN}

TTG alat pengering ikan tenaga surya menggunakan material utama Solar Collektor yang berfungsi menyerap energi radiasi matahari yang jatuh diatas permukaan plat penyerap sehingga temperatur plat menjadi tinggi. Kontruksi sel surya terdiri dari bagian bagian ; Pipe 
header, Pipa kolektor, Plat penyerap, Kaca isolator, Rumah panel, Isoolasi dan Blok ( Badan).

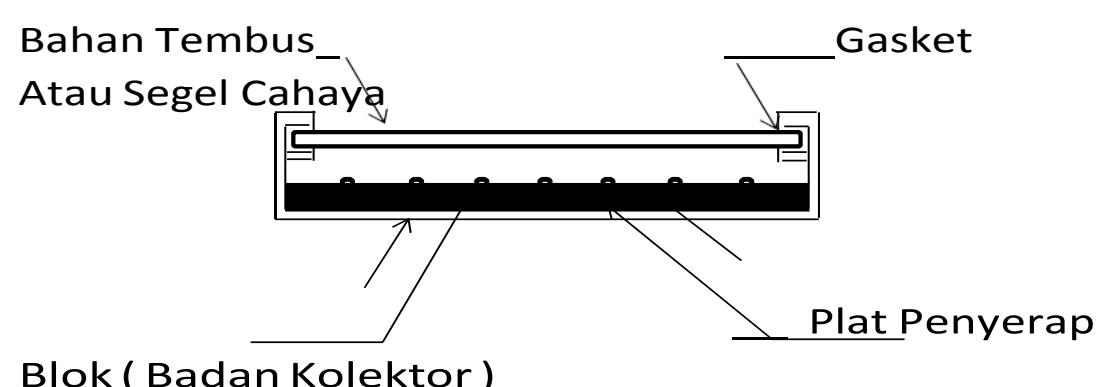

Sekat Lintasan Fluida

Gambar 4. Kontruksi sel surya

Kontruksi terdiri atas beberapa komponen utama yaitu:

1. Plat absorver berupa plat datar, biasanya dicat hitam.

2. Penutup transparan berupa kaca.

3. Isolasi panas diletakan pada bagian bawah plat penyerap.

4. Plat penyerap panas terbuat dari tembaga dan diberi lapisan untuk meningkatkan penyerapan energi sinar matahari.

5. Plat - plat penutup bertumpu pada rumah ( badan ) kolektor.

Plat penyerap pada kolektor berfungsi menyerap energi radiasi matahari, kemudian mengubahnya menjadi energi panas. Energi ini dipindahkan secara konduksi dan konveksi mengalir kedalam wajan penyimpan (penyimpan ikan), makin luas permukaan plat penyerap maka semakin banyak energy yang dapat diserap plat. Kehilangan panas ini dapat dikurangi dengan memasang kaca kaca penutup yang transparan terhadap radiasi matahari, tetapi tidak transparan terhadap radiasi panas, dengan demikian kehilangan panas akibat radiasi panas matahari kekolektor sekelilingi dapat dikurangi, dengan pemakaian kaca penutup, perpindahan panas konveksi akibat dari angin luar dapat dicagah. Selain plat, bahan plat, warna, intensitas radiasi matahari, laju aliran cahaya dan lainnya mengurangi performasi kolekor.

Dari uraian diatas kolektor dapat dianggap sebagai heat exachanger yang memindahkan panas dari radiasi matahari ke zat aliran kerja. Makin besar laju perpindahan panas dari plat kewajan dibandingkan panas dari plat ke air dibandingkan perpindahan panas yang diserap plat kolektor, performasi kolektor semakin baik. Performasi kolektor dapat dinyatakan dengan efisiensi thermalnya, efisiensi kolektor merupakan perbandingan energy yang diserap dan besarnya energi matahari yang jatuh mengenai plat. Perlu diingat bahwa intensitas radiasi matahari berubah menurut waktunya.

Adapun desain alat pengering ikan ini menggunakan sistem rak dengan komponen utama berupa : Panel surya, solar charge controller, batteray(aki), interver, temperature control, sensor suhu RTD, Lampu pijar, seperti gambar berikut : 


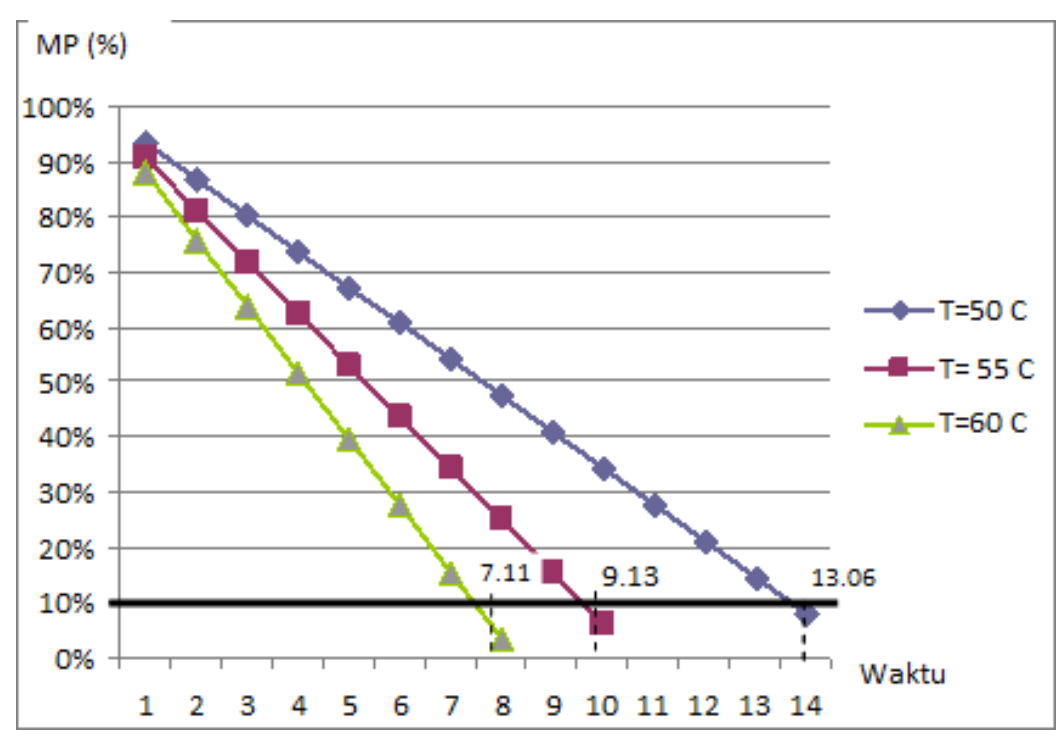

Gambar 5. Grafik Penurunan Kadar air dalam tubuh ikan

Desain ukuran ruang pengering Ikan dengan menggunakan data hasil perhitungan beban kalor yang dibutuhkan untuk alat pengering ikan berkapasitas $12 \mathrm{~kg}$ dan bisa dikembangkan menjadi 30-50 kg dengan ukuran alat sekitar 1,5 meter, dimana Qtotal diperoleh $35634.96 \mathrm{~kJ} /$ siklus pengeringan dan juga didapatkan kebutuhan kolektor untuk mendapatkan panas sebesar $1781.75 \mathrm{~kJ} / \mathrm{siklus}$ untuk kebutuhan kolektor yang digunakan mengeringkan $1 \mathrm{~kg}$ ikan air tawar basah berdasarkan perhitungan untuk memperolehenergi untuk mengeringkan ikan air tawar selama 7.11 jam maka setara dengan kolektor $3.65 \mathrm{~m}^{2}$. Jadi alat ini berfungsi untuk mengurangi kadar air didalam ikan berkisar antara $70-80 \%$ air terbuang.

\section{KESIMPULAN DAN SARAN}

Kesimpulan kegiatan PKM di desa Pejala Kabupaten Tanah Laut berjalan dengan baik di setiap tahapannya. Kerjasama diantara tim (ketua, anggota, tim workshop, tim dokumentasi) cukup harmonis. Adapun Tim Poliban dengan mitra (KUB), juga aparat desa begitu baik dan saling melengkapi.

Sehingga berdampak secara ekonomi dan social, yaitu Dampak ekonomi : (a) Secara kuantitas meningkatnya hasil produksi dari $70 \%$ menjadi $90 \%$ barang jadi/siap jual; (b) Secara kualitas meningkat, hasil produk lebih higienis; (c) Harga jual produk ikan asin bisa lebih tinggi. Adapun secara sosial berdampak : (a) Rasa ikan kering lebih enak, gurih dan bersih; (b) Menumbuhkan budaya berwirausaha bagi warga khususnya kelompok usaha; (c) Masayarakat terbiasa dengan alih teknologi secara bertahap; dan (d) Kesadaran warga meningkat untuk hidup sehat dengan menjual ikan yang higienis.

Saran di dalam kegiatan PKM ini waktunya bersamaan dengan merebaknya wabah Covid 19, sehingga kebijakan PSBB secara tidak langsung menghambat kegiatan, dan sulitnya memesan spare part alat secara cepat. Maka ada baiknya kedepan kegiatan semacam ini dapat dimulai dibulan-bulan awal pada tahun itu. 


\section{UCAPAN TERIMA KASIH}

Penulis mengucapkan terima kasih kepada Kemenristek BRIN,yang telah memberikan dana hibah untuk kegiatan PKM ini, Direktur Politeknik Negeri Banjarmasin, aparat desa di Pejala Kabupaten Tanah Bumbu, KUB dan warga setempat, dan Universitas Mataram yang telah mengadakan Semnas Pepadu II 2020, serta semua pihak yang tidak bisa penulis sebutkan satu persatu.

\section{DAFTAR PUSTAKA}

Afrianto, E., \& Liviawaty, E. (1994). Pengawetan dan pengolahan ikan. Kanisius: Yogyakarta.

Bintang, Y. M., Pongoh, J., \& Onibala, H. (2013). Konstruksi dan kapasitas alat pengering ikan tenaga surya sistem bongkar-pasang. Jurnal Media Teknoloi Hasil Perikanan, 1(2), 40-43.

Herlina Herlina, Dian Aswita, Ikramullah Zein (2020). Oven Solar Dryer Teknologi Sebagai Upaya Peningkatan Produksi Ikan Asin Pada Masyarakat Nelayan Di Gampong Deah Raya Kota Banda Aceh. Jurnal Panrita Abdi, Vol 4 (No.2), Juni 2020, Jurnal Panrita Abdi, Unhas Makasar 